\title{
CHARACTERISTICS AND LIQUEFACTION OF COAL FROM WARUKIN FORMATION, TABALONG AREA, SOUTH KALIMANTAN-INDONESIA
}

\author{
Edy Nursanto ${ }^{* 1}$, Arifudin Idrus ${ }^{2}$, Hendra Amijaya ${ }^{2}$, and Subagyo Pramumijoyo ${ }^{2}$ \\ ${ }^{1}$ Mining Engineering Department, Faculty of Mineral Technology, Pembangunan Nasional "Veteran" University \\ ${ }^{2}$ Geological Engineering Department, Faculty of Engineering, Gadjah Mada University
}

\begin{abstract}
Since the coal characteristic is the main controlling factors in coal liquefaction, thus five coal seams with different coal rank from Warukin Formation in Tabalong Area, South Kalimantan have been used in this study. Three seams were low rank coal (Wara 110, Wara 120, Wara 200) while two seams were medium rank (Tutupan 210 and Paringin 712). The objectives of this study was to investigate the effect of coal rank on the rate of coal conversion factor. Coal liquefaction was conducted in an autoclave on low pressure (14.7 psi) and temperature $120^{\circ} \mathrm{C}$. Experiments were designed with time intervals 30, 60 and 90 minutes, respectively. The average coal properties of seam Wara 110, Wara 120 and Wara 200 were $26.65 \%, 5.08 \%, 46.26 \%$ and $30.60 \%$ for inherent moisture, ash content, volatile matter and. fixed carbon, respectively. In contrast, coal properties for seam Tutupan 210 and Paringin 712 were $18.42 \%$, $1.81 \%, 23.02 \%$ and $35.76 \%$ for inherent moisture, ash content, volatile matter and fixed carbon, respectively. The maximum yields for Wara 110, Wara 120 and Wara 200 were $48.60 \%$ (30 minutes), $51.27 \%$ (60 minutes) and $46.72 \%$ (90 minutes). In comparison, Tutupan 210 and Paringin 712 resulted maximum yields of $8.22 \%$ (30 minutes), $18.35 \%$ (60 minutes), $6.23 \%$ (90 minutes). In conclusion, low
\end{abstract}

${ }^{*}$ Corresponding author: E. NURSANTO, Mining Engineering Department, Faculty of Mineral Technology, Pembangunan Nasional "Veteran" University. E-mail: edynursantoyyk@yahoo.com.au rank coal has higher yield conversion compared to medium rank coal since it has higher $\mathrm{H} / \mathrm{C}$ ratio.

Keywords: Coal liquefaction, low rank coal, Kalimantan.

\section{Introduction}

Increasing utilization of fossil fuel particularly coal is triggered by economic growth in Indonesia. Coal has been used directly as fossil fuel from decade for power plants, steel industries, transportation and many others industries from small to big scale. In the future, coal also has important role as indirect fuel which means coal is converted into other forms before utilized as a fuel. Coal liquefies into oil is one of the example as indirect fuel.

Present research focuses on examining the liquefaction process of several coals from Kalimantan, Indonesia which has different rank. The effect of coal characteristics and reaction time on liquefaction yields will be briefly examined.

\section{General geology}

Research area was located in Barito Basin, Kalimantan. Darman and Sidi (2000) explained that the Barito Basin is located along with the southeastern margin of the Schwaner Shield in South Kalimantan. Warukin Formation which consists of coal seams intercalated with sandstone 
and claystone is found in this area as well as Dahor Formation which is not a coal bearing formation. Morphologically it is a hilly terrain. Well known Tutupan hill ranges 20 miles in length, extending up from the North-East to South-West (Adaro Inc., 1997). This hill is formed and bordered by the movement of two thrust faults with a parallel direction. Fault located in west part of hill is known as Dahai fault serving as the western border of Dahor Formation. Another fault which becomes the eastern border of the hill is known as the reverse fault Tanah Abang-Tepian Timur.

\section{Samples and experimental methods}

\section{Samples}

Coal samples were obtained from Tabalong area, South Kalimantan-Indonesia and were classified as low rank coal. Sampling was conducted in the coal mining of Adaro Indonesia Inc (Figure 1). Research on coal liquefaction process was conducted in seam Wara 110, Wara 120, Wara 200, Tutupan 210 and Paringin 712. Typical of proximate and ultimate properties of the coals were shown in Table 1 and 2.

\section{Experimental methods}

The liquefaction experiments were conducted in autoclave bath-type with automatic temperature control, capable of producing a maximum pressure of $15 \mathrm{psi}$ at $120^{\circ} \mathrm{C} .1 \mathrm{~g}$ of coal sample with added alkali $(\mathrm{NaOH})$ in the range $0-0.025$ $\mathrm{mol} / \mathrm{g}(0.01 \mathrm{~g})$, alumina catalyst $0,03 \mathrm{~g}$ and solvent of water $39 \mathrm{~g}$ were mixed in the $50 \mathrm{~mL}$ cell. The coal slurry which is a mixing substance of coal, water, hydrogen donor, $\mathrm{NaOH}$ and catalyst then was put into the autoclave with temperature and pressure of $120^{\circ}$ and $14.70 \mathrm{psi}$. The temperature $120^{\circ} \mathrm{C}$ and pressure 14.70 psi were chosen based on previous studies by Stone and Park (1970) who conducted liquefaction of lignite and sub-bituminous coal. Liquefaction process was conducted on three variable reaction time i.e. 30, 60 and 90 minutes. After cooling down, cell of liquids is taken from autoclave. The coal slurry was filtered with Whatman paper no. 42 and dried with ambient temperature.

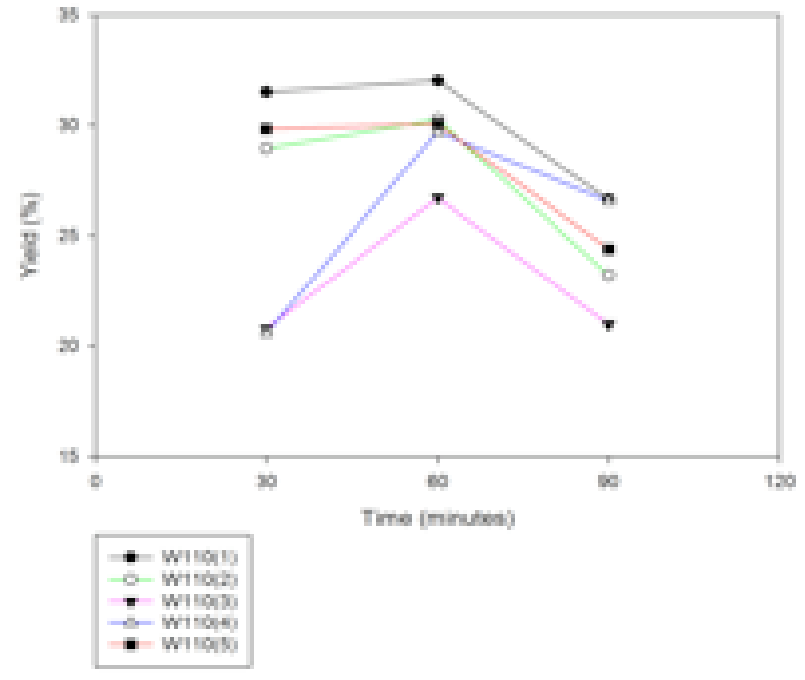

Figure 2: Correlation between liquefaction time and yields of Wara 110 coal.

Result of filtering and drying will be compared to calculate its yield.

\section{Characteristics of coal}

Based on inherent moisture and volatile matter as depicted in Table 1, the coal samples can be classified as lignite and sub-bituminous (see coal classification in Speight, 2005). Moreover, analysis of chemistry on Wara 110, Wara 120, Wara 200, Tutupan 210 dan Paringin 712 coals were shown on Table 2

\section{Results and discussion}

The maximum result of liquefaction process as function of time variable for seam Wara were $48.60 \%$ (30 minutes), $51.27 \%$ (60 minutes), and $46.72 \%$ (90 minutes). In case of seam Tutupan, the results were $8.22 \%$ (30 minutes), $18.35 \%$ (60 minutes) and 6.23\% (90 minutes). Furthermore, Paringin 712 resulted $4.20 \%$ (30 minutes), $11.95 \%$ (60 minutes) and 3.20\% (90 minutes). The average value of yield shows that coals in seam Wara has higher yield conversion compared to Tutupan and Paringin seam (see Table 3 and Figures $2-6$.

In general, low rank coal has higher hydroxyl group compared to high-rank coal. (Given, 1960 in Krevelen, 1992). Hydroxyl content leads to higher percentage of $\mathrm{H} / \mathrm{C}$ compounds. Thus, 


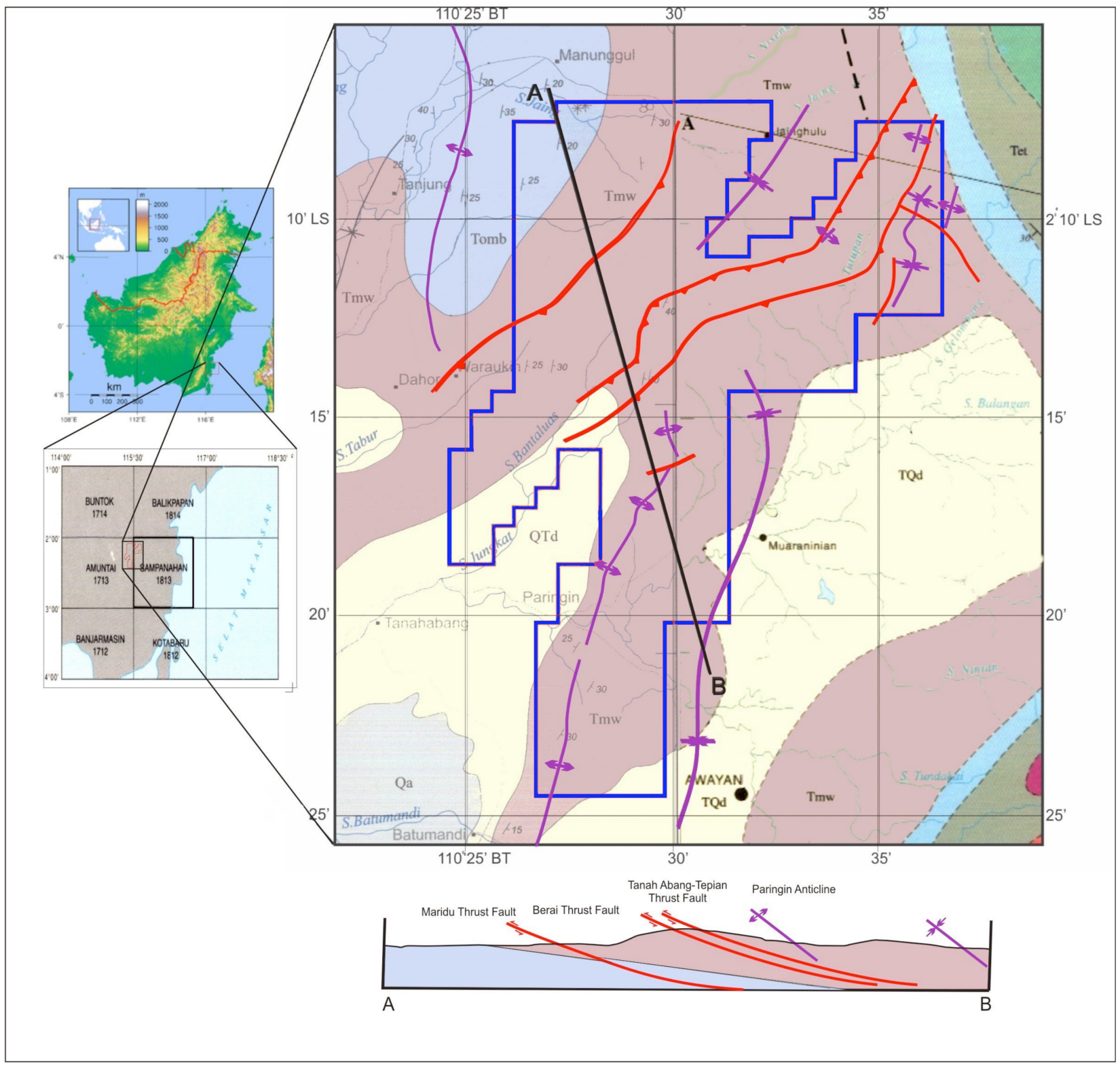

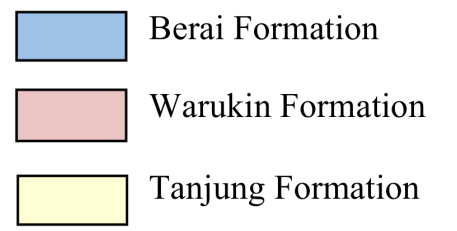

Tanjung Formation

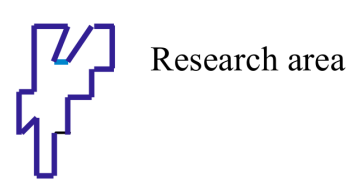

Pitap Formation

Aluvium

Figure 1: Geological map of research areay (Adaro Inc., 1997). 
Table 1: The results of proximate analysis of coal samples from study area.

\begin{tabular}{|l|c|c|c|c|}
\hline \multicolumn{1}{|c|}{ Seam } & Ash (\%) & IM (\%) & VM (\%) & FC (\%) \\
\hline Wara 110 & $1.24-1.74$ & $19.96-29.43$ & $40.60-49.46$ & $26.69-31.45$ \\
\hline Wara 120 & $3.57-6.11$ & $21.27-30.90$ & $35.28-49.67$ & $19.29-28.94$ \\
\hline Wara 200 & $0.68-0.94$ & $20.89-28.99$ & $39.57-48.20$ & $29.50-32.07$ \\
\hline Tutupan 210 & $1.31-2.87$ & $16.40-20.40$ & $44.80-47.70$ & $32.50-35.10$ \\
\hline Paringin 712 & $1.03-1.72$ & $12.89-18.77$ & $45.22-46.93$ & $34.29-39.46$ \\
\hline
\end{tabular}

Table 2: The results of elemental composition of coal samples from study area.

\begin{tabular}{|l|c|c|c|c|c|}
\hline \multicolumn{1}{|c|}{ Seam } & $\mathbf{C ~ ( \% )}$ & $\mathbf{H ~ ( \% )}$ & $\mathbf{N ~ ( \% )}$ & $\mathbf{S ~ ( \% )}$ & $\mathbf{H} / \mathbf{C}$ \\
\hline Wara 110 & $58.07-62.73$ & $5.64-5.92$ & $0.54-0.69$ & $0.07-0.11$ & $1.12-1.17$ \\
\hline Wara 120 & $57.11-61.52$ & $5.37-6.24$ & $0.52-0.68$ & $0.09-0.21$ & $1.13-1.28$ \\
\hline Wara 200 & $59.66-63.44$ & $5.82-6.26$ & $0.52-0.63$ & $0.10-0.39$ & $1.13-1.27$ \\
\hline Tutupan 210 & $61.59-62.45$ & $5.66-5.91$ & $1.02-1.08$ & $0.05-0.15$ & $1.09-1.14$ \\
\hline Paringin 712 & $61.15-64.16$ & $5.44-6.09$ & $1.18-1.25$ & $0.08-0.09$ & $1.07-1.17$ \\
\hline
\end{tabular}

Table 3: The result of coal liquefaction process of coal samples from study area.

\begin{tabular}{|l|c|c|c|}
\hline \multirow{2}{*}{ Sample } & \multicolumn{3}{|c|}{ Yield (\%) } \\
\cline { 2 - 4 } & $\mathbf{3 0}$ minutes & $\mathbf{6 0}$ minutes & $\mathbf{9 0}$ minutes \\
\hline Wara 110 & $17.37-31.49$ & $24.14-32.57$ & $20.98-26.83$ \\
\hline Wara 120 & $27.89-48.60$ & $31.85-51.27$ & $25.37-46.72$ \\
\hline Wara 200 & $11.75-23.89$ & $19.54-34.50$ & $15.76-29.49$ \\
\hline Tutupan 210 & $6.97-8.22$ & $11.61-18.35$ & $3.02-6.23$ \\
\hline P aringin 712 & $2.14-4.20$ & $5.99-11.95$ & $1.99-3.20$ \\
\hline
\end{tabular}




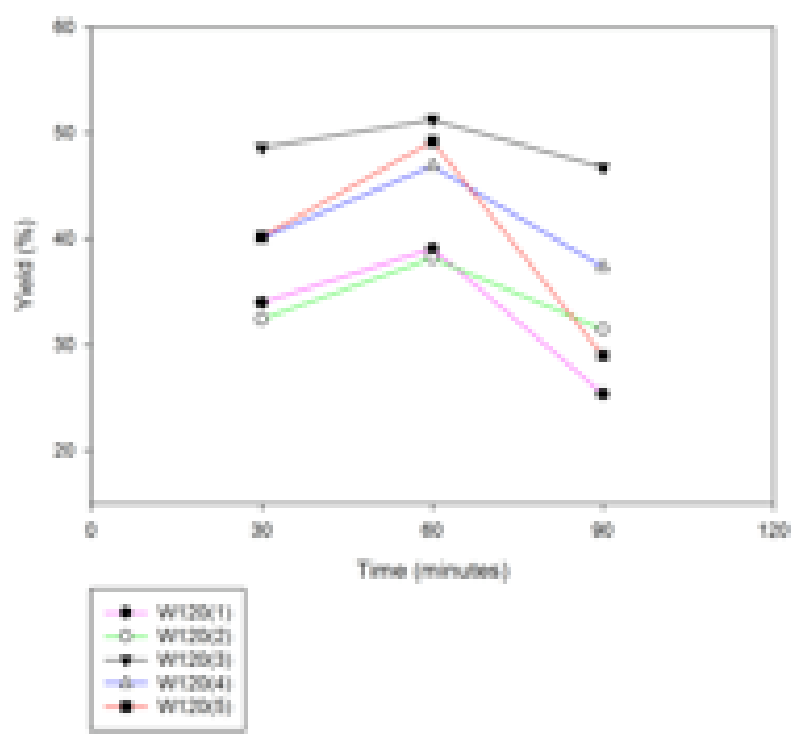

Figure 3: Correlation between liquefaction time and yields of Wara 120 coal.

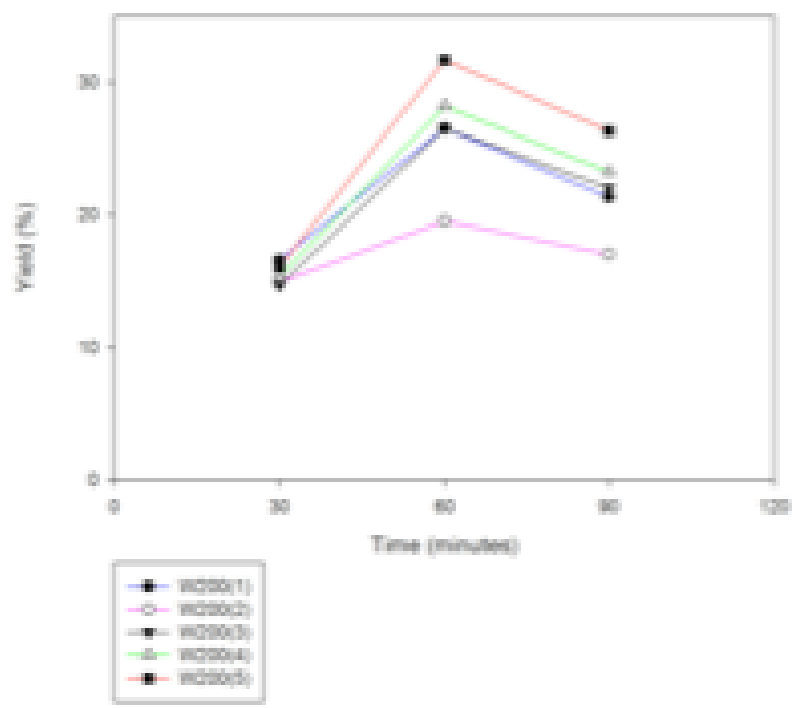

Figure 4: Correlation between liquefaction time and yields of Wara 200 coal.

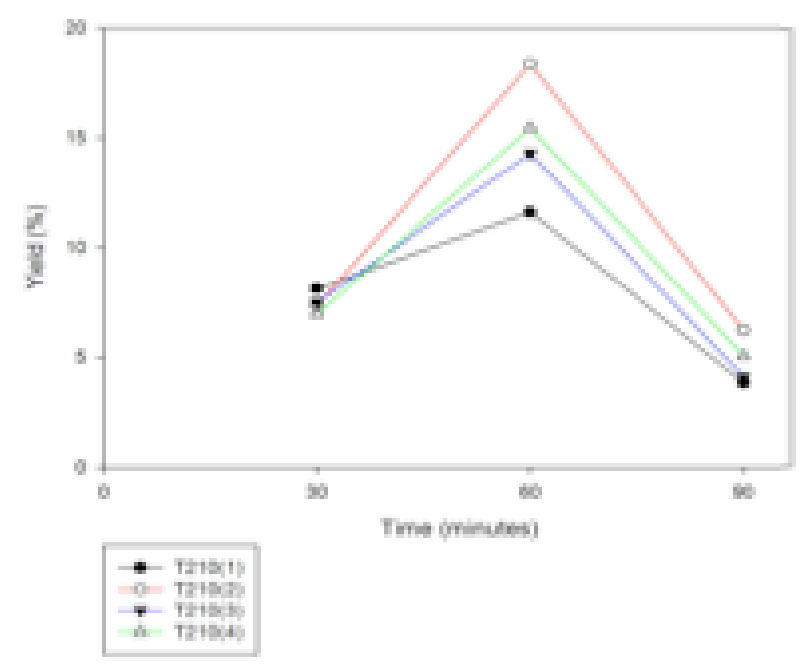

Figure 5: Correlation between liquefaction time and yields of Tutupan 210 coal.

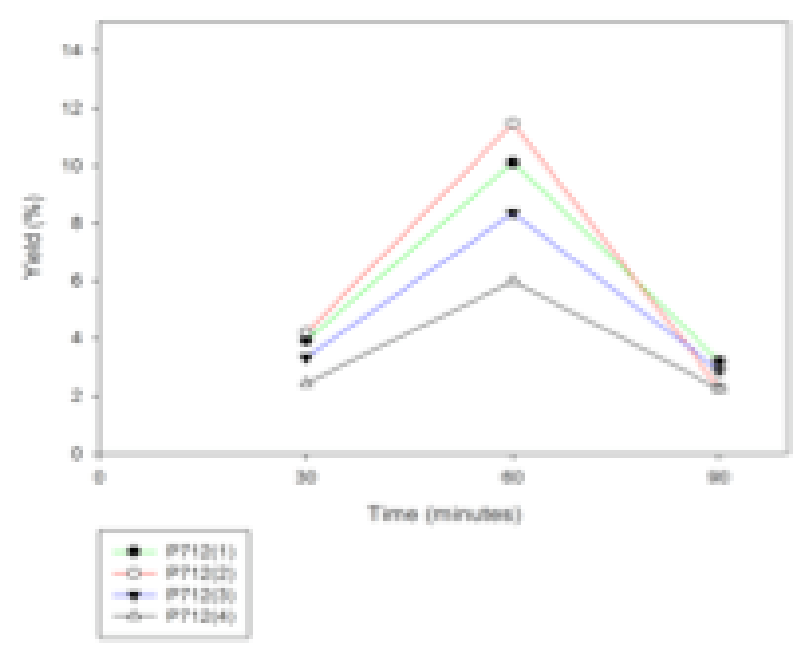

Figure 6: Correlation between liquefaction time and yields of Paringin 712 coal. 
low-rank coal is easier to be converted. Wara coal is lignite and is classified into low-rank coal. It has $\mathrm{H} / \mathrm{C}$ ratio of maximum 1.28. In contrast to Tutupan and Paringin seam which is classified as medium rank coal, the $\mathrm{H} / \mathrm{C}$ ratio was only 1.17 .

A fundamental study by Whitehurst (1978) stated that high hydrogen content in coal results in higher conversion percentage than in coal with low hydrogen content. Moreover, low-rank coal such as lignite is known to produce more oil during liquefaction process compared to high-rank coals such as sub-bituminous, bituminous, and anthracite (Speight, 1994).

Increasing conversion factors of liquefaction from 30 minutes to 60 minutes reaction times was controlled mainly by chemical reaction processes. A long reaction time gives opportunity for coal to have more contact with solvent and hydrogen donor. Hence, longer reaction times give higher conversion result. This phenomenon also has been reported by previous studies (Vassallo et al., 1983; Priyanto et al., 2001; and Maloletnev, 2009). They concluded that the longer reaction time of liquefaction process, the higher result will be obtained.

\section{Conclusions}

Based on its characteristics, the rank of coals in Tabalong, South Kalimantan are lignite for seam Wara 110, Wara 120 and Wara 200 while Tutupan 210 and Paringin 712 coals are subbituminous. Lignite coal tend to have better result in liquefaction process compared to subbituminous coal. This is due to higher $\mathrm{H} / \mathrm{C}$ ratio of lignite coal than sub-bituminous coal.

Increasing percentage of liquefaction process only occurred for the reaction time of 30 to 60 minutes. In case of 90 minutes reaction time, the result of liquefaction process was decreasing. Maximum yield of Wara coal was 51.27\% in 60 minutes reaction time and decreasing to $46.72 \%$ in 90 minutes reaction time. This phenomenon was also observed for Tutupan and
Paringin seam where the maximum yield of 60 minutes reaction time was $18.35 \%$ and decreasing to $6.23 \%$ in 90 minutes reaction times.

\section{Acknowledgement}

We express our deepest gratitude to the management of Adaro Indonesia Inc. for giving permission to collect samples and other support during the field research.

\section{References}

Adaro Indonesia Inc. (1997) Adaro Resources Report, Departemen Geologi PT. Adaro Indonesia.

Darman, H. dan Sidi , F.H. (2000) An Outline of The Geology of Indonesia, Indonesian Association of Geologist (Ikatan Ahli Geologi Indonesia-IAGI), p.69-73.

Krevelen, D.W. (1992) Coal Typology-PhysicsChemistry-Constitution. University Of Technology, Delft, The Netherlands. 750p.

Maloletnev, A.S. (2009) Current Status of The Hydrogenation of Coal, Solid Fuel Chemistry, Vol. 43, pp. 165-176.

Priyanto, U., Sakanishi K., Okima O., Murti S.D.S., Watanabe I, Korai Y., Mochida I. (2001) Optimization of Two-Stage Liquefaction of Tanito Harum Coal With Fe-Ni Catalyst Supported Carbon Black, Energy \& Fuel, pp. 856862.

Speight, J.G. (1994) The Chemistry and Technology of Coal, Marcel Dekker Inc., New York, $642 p$.

Speight, J.G. (2005) Handbook of Coal Analysis, John Wiley \& Sons, Inc., Publication, 222p.

Stone, R.D. and Park, L.G. (1970) Coal Liquefaction Process. Patented, United States Patent Office, $4 p$.

Vassallo, A.M., Fredericks P.M., and Wilson M.A.(1983) FTIR Studies of Deutorium Incorporation In to Coal, Associated Mineral Matter and Hydrogenation Residues, Organic Geochemistry, Vol.5 No.2, pp. 75-85.

Whitehurst, D.D. (1978) A Primer on the Chemistry and Constitution of Coal, American Chemical Society, pp. 1-35. 